\title{
Expression of the Potent Vasoconstrictor Endothelin in the Human Central Nervous System
}

\author{
Mu-En Lee," Suzanne M. de la Monte, ${ }^{\star}$ Shi-Chung Ng, ${ }^{\star 5}$ Kenneth D. Bloch, ${ }^{\star}$ and Thomas Quertermous* \\ *Department of Medicine, Harvard Medical School and Cardiac Unit, General Medical Services, Massachusetts General Hospital, \\ Boston, Massachusetts 02114; ${ }^{\ddagger}$ Department of Pathology, Harvard Medical School and Molecular Hepatology Laboratory, General \\ Medical Services, Massachusetts General Hospital, Boston, Massachusetts 02114; and ${ }^{\S}$ The Bristol-Myers Squibb Pharmaceutical \\ Research Institute, Princeton, New Jersey 08543
}

\begin{abstract}
Endothelin is a potent vasoconstrictive peptide initially characterized as a product of endothelial cells. To examine the potential role of endothelin as a neuropeptide, we studied its distribution in the human central nervous system. RNA blot hybridization provided evidence of endothelin gene transcription in a variety of functional regions of the brain. In situ hybridization confirmed the widespread pattern of endothelin transcription and indicated that the highest density of cells containing endothelin mRNA is in the hypothalamus. This technique localized endothelin transcription to cells of the nervous system as well as the vascular endothelium. Immunocytochemical studies detected endothelin immunoreactivity in neurons, providing evidence of the synthesis of the peptide in this cell type and confirming that endothelin is a neuropeptide. Although the prominent expression of endothelin in the hypothalamus may indicate a central vasoregulatory role for the peptide, the widespread distribution of endothelin in neurons in other areas of the brain implies a more fundamental role in the regulation of nervous system function. (J. Clin. Invest. 1990. 86:141-147.) Key words: endothelin • neuropeptide • endothelium
\end{abstract}

\section{Introduction}

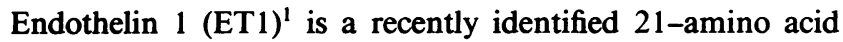
peptide produced by vascular endothelium in culture and in vivo (1). ET1 is the most potent known vasoconstrictor, and it has mitogenic activity in a number of mesenchymal cell types (2-5). The effects of ET1 on target cells appear to be mediated by activation of the dihydropyridine-sensitive calcium channel and phospholipase $\mathrm{C}, \mathrm{Na}^{+} / \mathrm{H}^{+}$exchange, and increased intracellular calcium (3-6). Two homologous genes that predict similar 21-amino acid vasoconstrictive peptides, endothelin 2 (ET2) and endothelin 3 (ET3), have been described (7). Although there is no evidence that the ET2 locus is transcribed, a cDNA clone encoding the ET3 preprohormone transcript has been characterized (8). It is thus likely that a family of homologous endothelin peptides exists, perhaps allowing intricate regulation of vascular tone.

Address reprint requests to Dr. Quertermous, Cardiac Research, Jackson 13, Massachusetts General Hospital, Boston, MA 02114.

Received for publication 17 July 1989 and in revised form 5 March 1990.

1. Abbreviations used in this paper: ET, endothelin.

J. Clin. Invest.

(c) The American Society for Clinical Investigation, Inc.

0021-9738/90/07/0141/07 \$2.00

Volume 86, July $1990,141-147$
Little is known about tissue- and cell type-specific endothelin gene expression. Inoue et al. (7) observed ET1 gene transcription in endothelial cells, but were unable to detect transcription of the ET1, ET2, or ET3 gene in a variety of human tissues including the brain. In experiments with 3'-untranslated ET1 and ET3 cDNA fragments that do not crosshybridize, our laboratory has detected expression of these genes in human heart, kidney, lung, spleen, and pancreas (8), although we have not identified the cell types responsible for transcription. Endothelin binding sites have been demonstrated in a number of rat tissues including heart, lung, intestine, adrenal gland, and arterial smooth muscle (9). In addition, endothelin binding sites have been demonstrated in brain tissue, and ET1 has been shown not to cross the blood-brain barrier (9). This would imply that one of the endothelins or a related peptide is synthesized in cells within the brain. A number of other peptides with cardiovascular functions, such as atrial natriuretic peptide and angiotensin, are expressed in both the brain and peripheral tissue $(10,11)$. Finally, endothelium-dependent relaxing factor has recently been shown to function as a neuromodulator by serving as an intercellular messenger in the brain (12).

In this study we demonstrate the presence of mRNA in cells of the nervous system that hybridize to an ET1 cDNA. In addition, we show that neurons synthesize a protein recognized by an antibody directed against ET 1 .

\section{Methods}

Source of human brain tissue. The brain tissue used in these studies was obtained from nine individuals treated regularly at the Massachusetts General Hospital (Boston, MA) who died of systemic diseases and had no clinical evidence of neurological disease. There were no neuropathological findings in these patients at autopsy. Some of the RNA samples used in the RNA blots were made from the tissue of a 16-yr-old patient with cystic fibrosis. He died from a respiratory arrest, and at autopsy had embolic infarcts in multiple organs including the brain. There was no underlying neurological illness in this patient, and all brain tissue used in the preparation of RNA had normal histology except area 17, which had evidence of acute infarction.

Post-mortem human brain tissue from the frontal, temporal, parietal, and occipital cortex with underlying white matter, the striatum, hypothalamus, hippocampus, amygdala, and cerebellum were obtained within $8 \mathrm{~h}$ of death, snap-frozen in 2-methyl butane cooled with dry ice, and stored at $-80^{\circ} \mathrm{C}$ until use. A portion of the tissue was assayed by RNA blot hybridization. The remainder was used for in situ hybridization and immunocytochemical studies. Tissue blocks immediately adjacent to those frozen were embedded in paraffin, sectioned (8 $\mu \mathrm{m}$ thick), dewaxed, rehydrated, and used for immunohistochemistry.

RNA blot hybridization. Cellular RNA from various regions of the adult brain was prepared by guanidinium isothiocyanate extraction and centrifugation through cesium chloride (13). RNA was resus- 
pended in TE (10 mM Tris, $1 \mathrm{mM}$ EDTA, pH 7.6) and quantitated by determining optical density at $260 \mathrm{~nm} .10 \mu \mathrm{g}$ of each RNA was fractionated on a $1.3 \%$ formaldehyde-agarose gel and equal loading of the samples was verified by ethidium bromide staining of the gel. RNA was transferred to Nitroplus 2000 nylon membranes (Micron Separations Inc., Westboro, MA) and hybridization was performed with a ${ }^{32} \mathrm{P}-\mathrm{la}-$ beled, random-primed, 1.2-kb Eco RI fragment of an ET1 cDNA or a 1.9-kb Sac I fragment of a von Willebrand factor cDNA for $16 \mathrm{~h}$ at $37^{\circ} \mathrm{C}$ according to standard techniques $(14,15)$. In addition, a $1.3-\mathrm{kb}$ Pst I-Eco RI restriction fragment containing the 3'-untranslated portion of an ET3 cDNA was used to probe the blots (8). After each hybridization the blot was washed in $150 \mathrm{mM}$ sodium chloride, $15 \mathrm{mM}$ sodium citrate, and $0.1 \%$ SDS at $55^{\circ} \mathrm{C}$ and exposed to Kodak XAR film for $72 \mathrm{~h}$ at $-70^{\circ} \mathrm{C}$

In situ hybridization. A 701-bp Eco RI-Hind III ET1 cDNA restriction fragment was cloned into the pGEM3 vector, and sense and antisense cRNA transcripts were synthesized with T7 and SP6 polymerases (Promega Corp., Madison, WI) in the presence of ${ }^{35}$ [S]UTP to a specific activity of $10^{8}-10^{9} \mathrm{dpm} / \mu \mathrm{g}$. Sections were fixed in $4 \%$ paraformaldehyde and treated with $0.3 \%$ Triton X-100 followed by $1 \mu \mathrm{g} / \mathrm{ml}$ of proteinase $K(16,17)$. After acetylation the sections were hybridized for $16 \mathrm{~h}$ at $50^{\circ} \mathrm{C}$ with $\sim 10^{6} \mathrm{dpm}$ of ${ }^{35}$ [S]UTP-labeled antisense (or sense) cRNA probe per $\mathrm{cm}^{2}$ of tissue. The slides were washed for 15 min (four times) in a solution of $1 \times$ SSC $(300 \mathrm{mM}$ sodium chloride and $30 \mathrm{mM}$ sodium citrate), $10 \mathrm{mM}$ DTT, $50 \%$ formamide, and $0.5 \%$ Triton X-100 at $50^{\circ} \mathrm{C}$. cRNA probe was digested with $50 \mu \mathrm{g} / \mathrm{ml}$ RNAse $A$ in $10 \mathrm{mM}$ Tris and $1 \mathrm{mM}$ EDTA containing $10 \mathrm{mM}$ DTT. Sections were further washed in $2 \times$ SSC with $1 \mathrm{mM}$ DTT and then $0.2 \times \mathrm{SSC}$ with $1 \mathrm{mM}$ DTT (each step for $30 \mathrm{~min}$ at $37^{\circ} \mathrm{C}$ ). The sections were dehydrated through graded alcohol solutions containing $0.3 \mathrm{M}$ ammonium acetate. The slides were coated with Kodak NTB2 emulsion and exposed for 1-2 wk.

Immunocytochemistry. Cryostat sections adjacent to those used for in situ hybridization were immunolabeled with a 1:100 dilution of a rabbit polyclonal antibody to ET1 (Peninsula Laboratories, Inc., Belmont, CA) using the avidin-biotin-horseradish peroxidase method
(Vector Laboratories, Inc., Burlingame, CA) according to the manufacturer's protocol. Paraffin-embedded sections fixed in $10 \%$ formaldehyde were treated with $0.1 \%$ trypsin for $10 \mathrm{~min}$ at $37^{\circ} \mathrm{C}$ before immunostaining. The sections were examined by both bright- and dark-field microscopy.

\section{Results}

RNA blot hybridization was used to identify mRNA transcribed from one or more of the endothelin genes (ET mRNA). RNA samples from a variety of human brain and spinal cord regions were analyzed by hybridization with a 1.2-kb Eco RI fragment of a previously characterized ET1 cDNA (14). Hybridization to a $2.1-\mathrm{kb}$ message (Fig. 1) indicated the presence of ET mRNA in most of the samples, with the lane containing RNA from the striatum revealing the greatest activity. ET mRNA detected by blot hybridization could reflect endothelin gene expression in endothelial cells of the vasculature of the brain. To evaluate the contribution by endothelial cells to the ET mRNA detected by hybridization in each of the tissue RNA samples, a separate hybridization to an endothelial cellspecific probe (von Willebrand factor) was performed (Fig. 1). The different pattern of hybridization between these two probes provided evidence that the signal observed with the ET1 probe did not reflect ET mRNA restricted to blood vessels. This data suggested that one or more of the endothelin genes might be expressed in the brain and spinal cord in cells other than endothelial cells. When this same RNA blot was studied with a 3 '-untranslated probe specific for ET3 mRNA, no hybridization was observed (8, data not shown). Thus, it is unlikely that the ET mRNA represents expression of this member of the endothelin gene family.

To determine which cells of the central nervous system
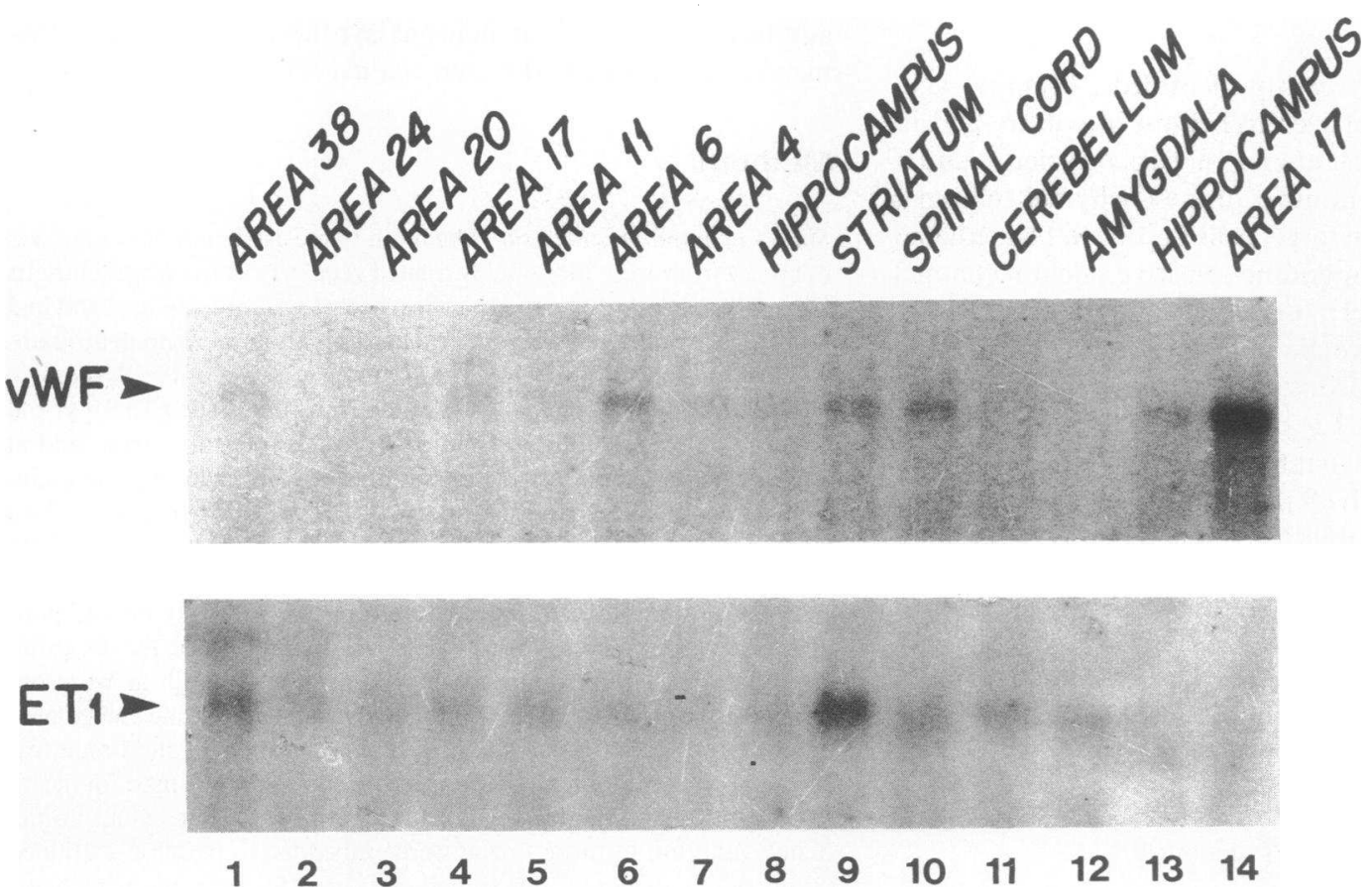

Figure 1. RNA blot hybridization analysis of human central nervous system tissue RNAs. RNA was prepared using standard techniques (12) from tissue samples derived from various regions of the brain and spinal cord. Tissue was obtained at autopsy from a 16-yr-old man (lanes 1-12) or from a patient with a stroke in the region of area 17 (lanes 13 and 14). The RNA was electrophoresed, blotted, and hybridized to a ${ }^{32} \mathrm{P}$ labeled 1.2-kb Eco RI fragment of ET1 CDNA and to a 1.9-kb von Willebrand factor $(v W F)$ cDNA fragment $(13,23)$. Hybridization of the ET 1 probe to most RNA samples is evident, and is most prominent in the

sample derived from the striatum. Hybridization of the vWf probe has a different distribution, with maximum labeling of RNA from the area of tissue infarction in the stroke victim (area 17, lane 14). 

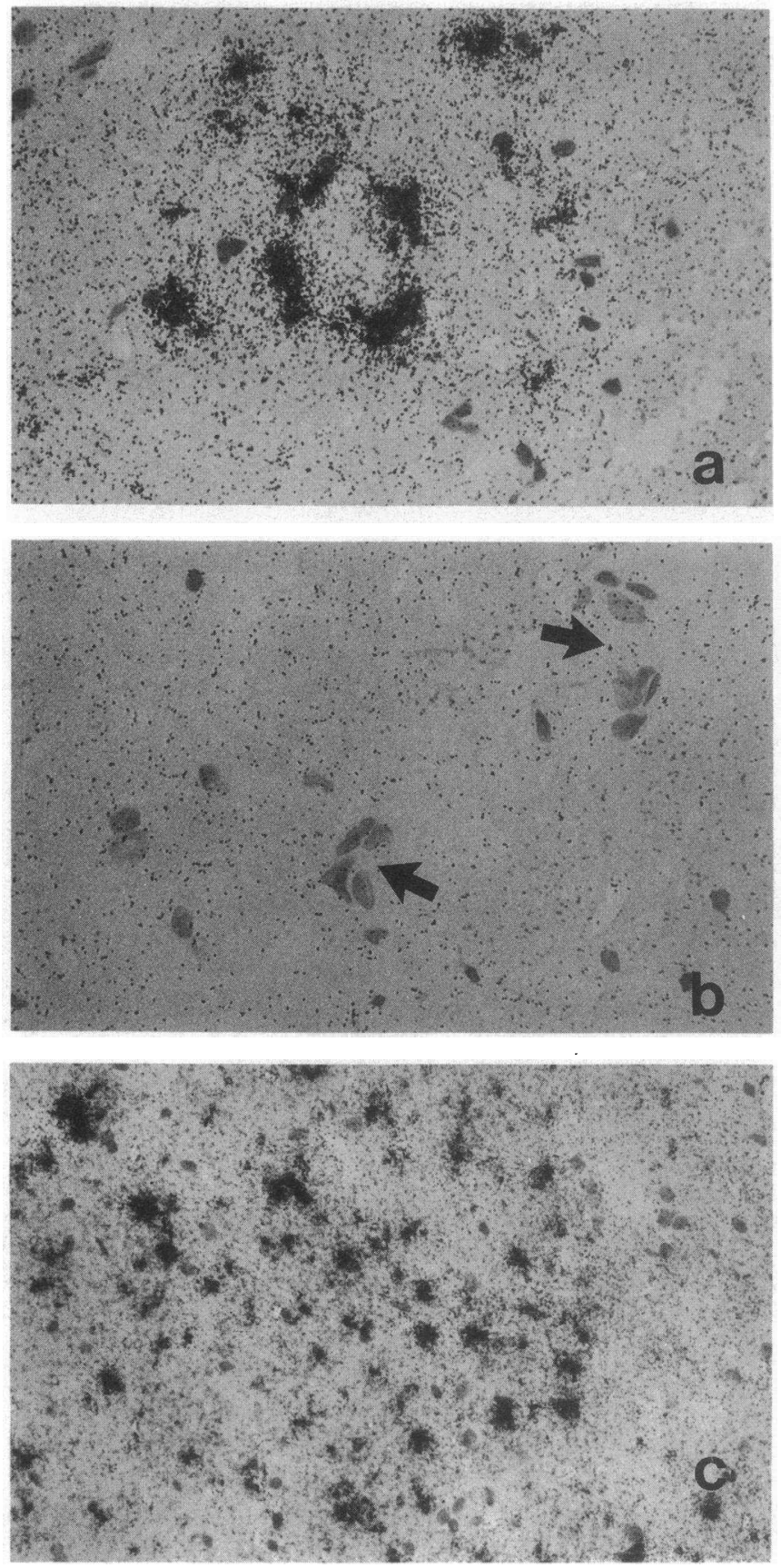

Figure 2. Endothelin mRNA expression in endothelial cells and neuroectodermal cells in human brain tissue. In situ hybridization was performed on cryostat sections of tissue from various brain regions (obtained from four adults with no neuropathological lesions). $a$, With the antisense cRNA probe, intense staining of endothelial cells is apparent in the medium-size, widely distended blood vessel in this section from the cerebral cortex. The other stained cells are also probably endothelial in nature and belong to blood vessels that have collapsed or are partially out of the plane of section. $b$, Note the absence of endothelial cell staining (arrows) with the sense cRNA probe in a section adjacent to the one in $a$. $c$, Intense labeling of neuroectodermal cells in hypothalamic grey matter. The characteristic singlecell pattern of staining corresponds to the distribution of neuronal and glial cells. Stained endothelial cells may also be among them but cannot be distinguished. Compared with other regions, the hypothalamus showed the most prominent staining. $\times 544$. transcribe the endothelin genes, we performed in situ hybridization on human brain tissue obtained from four adults without neuropathologic lesions. Both sense and antisense cRNA probes, derived from a 701-bp fragment of an ET1 cDNA, were radiolabeled with ${ }^{35}$ [S]UTP. When the antisense probe was hybridized to the tissue sections, intense labeling of endothelial cells was observed (Fig. $2 a$ ); equivalent amounts of sense RNA probe failed to label endothelial cells (Fig. $2 b$ ).

Labeling of neuroectodermal cells in the cerebral cortex and subcortical nuclei was observed with the ET1 antisense cRNA probe. In general, the intensity of labeling in these cells was low compared with endothelial cells. However, the density of labeled cells and the intensity of labeling were striking in grey matter of the striatum and, to an even greater extent, in the hypothalamus. These labeling characteristics were comparable to those observed for endothelial cells (Fig. $2 c$ ). Although cells containing ET mRNA could not be absolutely identified, most appeared to be neuronal. The characteristic single-cell pattern of the labeled cells within the neuropil supports this conclusion. Comparison of antisense-probed sections with adjacent sections hybridized with the sense cRNA probe demonstrates specificity of binding to mRNA. The possibility of glial cell labeling cannot be excluded in this type of study, however.

To determine whether the ET mRNA detected by RNA blot and in situ hybridization was associated with protein synthesis, we performed immunohistochemical studies on cryostat sections adjacent to those used in the in situ hybridization studies, as well as paraffin-embedded sections of hypothalamus from four additional patients. Although the commercially available rabbit polyclonal antibody (Peninsula Laboratories, Inc.) was raised by immunization with the ET1 peptide, the antibody is known to cross-react with ET3 and is very likely to cross-react with ET2 (ET2 and ET1 share 19 of 21 amino acids). Endothelin immunoreactivity may thus represent expression of one or more endothelin peptides.

Intense immunostaining of vascular endothelial cells from medium- and large-diameter parenchymal and arachnoidal blood vessels was evident in all sections (Fig. 3,al and b), and when the antibody was adsorbed to a 30-fold excess of purified ET1 peptide before application to the cryostat sections endothelin immunoreactivity was abolished (Fig. 3 a2). Examination of the sections by bright-field microscopy revealed only low-level immunoreactivity in neuroectodermal cells, which is consistent with observations from the in situ hybridization studies. To increase the visibility of stained structures and to better appreciate the distribution of endothelin immunoreactivity in neuroectodermal cells, we examined the sections by dark-field microscopy. The dark-field examination (Fig. $3 b$ ) revealed a larger number of immunoreactive small blood vessels than could be detected by bright-field examination. Diffuse, low-level endothelin immunoreactivity was evident in neurons scattered throughout the brain. For example, in the CA3 region of the hippocampal formation most of the pyramidal neurons were stained (Fig. $3 c$ ), and endothelin immunoreactivity was evident in cell bodies and neural processes (Fig. $3 d$ ).

High magnification provided convincing evidence of endothelin immunoreactivity in the cytoplasm of various cell types. Most striking was the immunostaining in the cytoplasm of vascular endothelial cells (Fig. $4 \mathrm{~A}$ ). Among neuronal cells, 

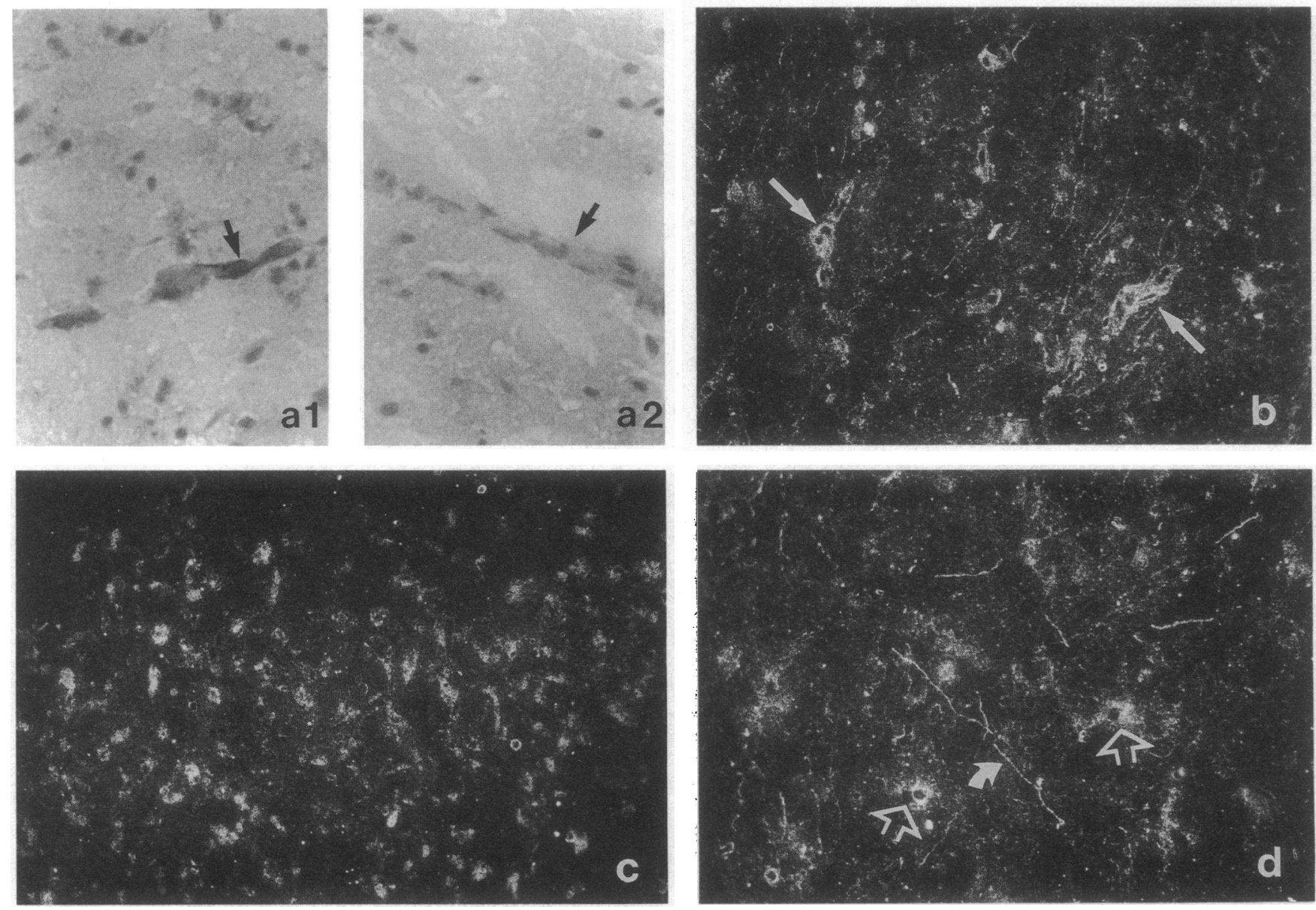

Figure 3. Immunocytochemical demonstration of endothelin immunoreactivity in the human brain. Cryostat sections adjacent to those used for in situ hybridization were immunolabeled with rabbit polyclonal antibody to ET1 (Peninsula Laboratories, Inc.) by the avidin-biotin-horseradish peroxidase method. The sections were examined by both bright- and dark-field microscopy. al, Note the intense immunoreactivity in endothelial cells (arrows). a2, All specific binding was abolished when the antibody was preadsorbed to an excess of ET1 peptide (arrow indicates unstained endothelial cells in a blood vessel). Dark-field illumination disclosed (b) a larger number of stained blood vessels (arrows), ( $c$ ) low-level immunoreactivity in many neurons including the pyramidal cells of the hippocampal formation (CA3 region shown), and (d) immunostaining of neuroectodermal cell bodies (open arrows) and neural processes (curved arrow) in the temporal cortex. $\times 260$.

endothelin immunoreactivity was most apparent in magnocellular neurons of the supraoptic and periventricular nuclei in the hypothalamus (Fig. 4, $B-E$ ). However, low levels of endothelin immunoreactivity were detected in neurons of all sizes in most hypothalamic nuclei and elsewhere in the brain. There appeared to be significant variability in the number of endothelin-containing cells in the hypothalamus between the different specimens of hypothalamic tissue (Fig. 4, B-E).

\section{Discussion}

In this study we demonstrated that endothelin gene expression is not limited to the vascular system. Both RNA blot hybridization analysis and in situ hybridization indicate that ET mRNA is present in cells in various brain regions with diverse functions. Immunocytochemical studies show a widespread distribution of endothelin immunoreactivity and provide convincing evidence that one or more of the endothelin peptides are synthesized in neurons of the central nervous system. Endothelin thus joins the growing list of neuropeptides known to have well-described functions outside of the nervous system. The diffuse distribution of endothelin-producing neurons contrasts sharply with the discrete localization of neurons producing other vascular peptides such as atrial natriuretic factor, vasopressin, and angiotensin II (18). However, the distribution of neurons containing endothelin is similar to that of neurons containing substance $P$, neurotensin, and cholecystoki$\operatorname{nin}(18)$.

The diffuse distribution of endothelin-containing neurons suggests that this peptide may function as a general intercellular messenger, either directly as a neurotransmitter or indirectly as a modulator of neurotransmission by other factors. This function in the brain could be completely unrelated to the peptide's function as a vasoconstrictor. The role we postulate for endothelin is quite similar to one recently ascribed to another vasoregulatory substance, endothelium-dependent relaxing factor. This vascular relaxing factor appears to perform a role in neurotransmission in the cerebellum that is unrelated to its vasodilatory role in the blood vessel wall (12).

The distribution of endothelin-containing neurons is wide- 


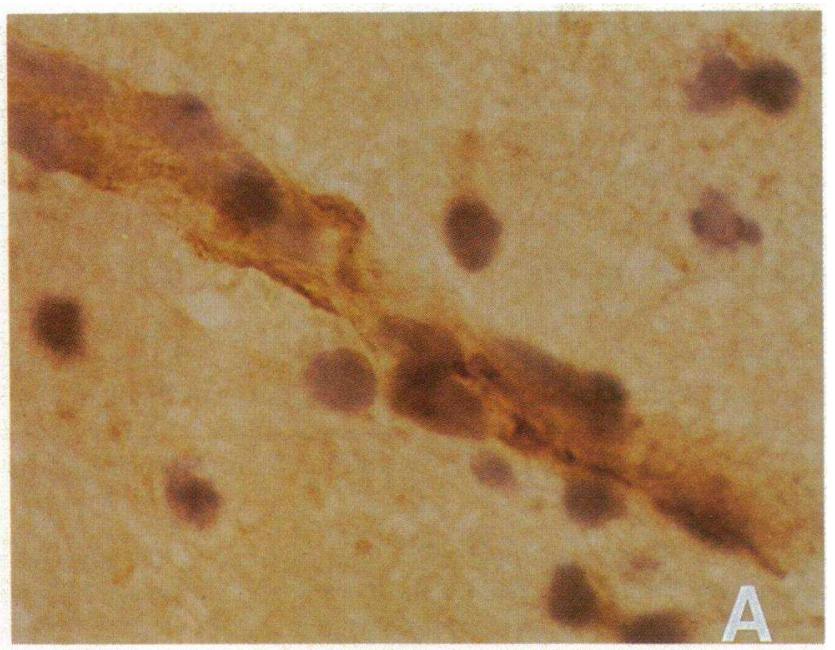

Figure 4. Cellular localization of endothelin immunoreactivity in the brain. $A$, Immunoreactivity is intense in endothelial cell cytoplasm (dark brown precipitate) and minimal or absent in scattered individual glial cells. $B-E$, Immunolabeling in neurons within the periventricular nuclei of the hypothalamus. Considerable variability is noted with some specimens showing labeling of a large percentage of neurons $(D$ and $E$ ), and other specimens showing less labeling $(B$ and $C) . B$ and $D, \times 300 ; C$ and $E, \times 500$.
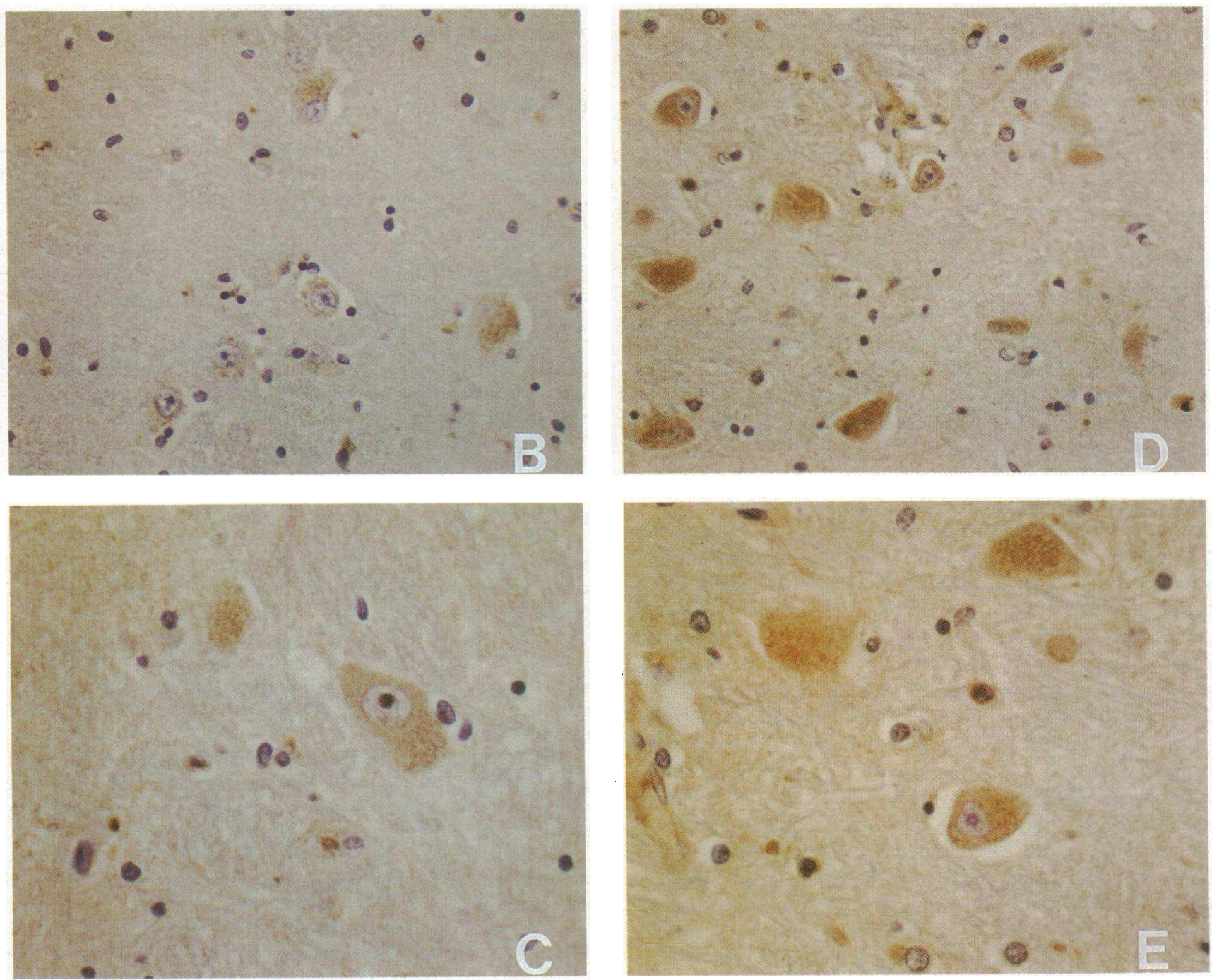
spread, but the density is highest in the hypothalamus. It is not surprising that endothelin-containing neurons as well as specific endothelin binding sites are most abundant in the hypothalamic region, an area that is important in the regulation of blood pressure and blood volume. Preliminary data suggest that ET1 administered intracerebroventricularly causes an increase in blood pressure (19). Thus, endothelin may modulate the regulation of blood pressure indirectly through the central nervous system and directly through the peripheral vascular system. It has been suggested that angiotensin II and atrial natriuretic factor regulate blood pressure and blood volume through a similar dual action $(10,11)$.

Although the nucleic acid probes and antibodies used in these studies derive from the endothelin first described by Yanagisawa et al. (1), i.e., ET1, the data reported here may reflect expression of other members of an endothelin gene family. Recently Inoue et al. cloned and characterized two genomic fragments containing sequences homologous to DNA encoding the original ET1 (7). These sequences predict the related 21-amino acid peptides ET2 and ET3. ET2 and ET3 differ from ET1 by two and six amino acids, respectively. Given the amino acid sequence homology among these peptides and the fact that they cross-hybridize at the genetic level, it is difficult to be certain about which endothelin gene is expressed in the human brain. The commercial polyclonal antibody used in our studies was raised against the complete 21-amino acid ET1 peptide; thus the antibody would be expected to cross-react with peptides encoding ET2 or ET3. Because the DNA and RNA probes we used were derived from an ET 1 cDNA and contained sequences encoding ET1 (14), the cDNA probe could have detected mRNA from the ET2 or ET3 genes on the RNA blot (the hybridization and washing conditions were not stringent). However, the likelihood of ET2 and ET3 transcripts being detected was less in the in situ experiments, in which the washing conditions were stringent. Thus, although we cannot be certain about which endothelin mRNA we detected, ET1 mRNA seems most likely.

Further evidence of ET1 expression in the brain comes from cDNA clones isolated from a human hypothalamic library. These clones hybridize to a 3'-untranslated ET1 cDNA fragment under stringent conditions and probably represent ET1 cDNAs (Bloch, K. D., and T. Quertermous, unpublished observations). It is clear that ET3 is expressed in the hypothalamus as well, since we have cloned and characterized ET3 cDNAs from the same library (8). However, ET3 expression appears to be limited to the hypothalamic region of the brain because we have been unable to detect ET3 mRNA in other brain regions by RNA blot hybridization.

The effect of endothelin on calcium channels also points to a neuronal function for this peptide. Endothelin has been shown to activate the dihydropyridine-sensitive, voltage-dependent calcium channel in vascular smooth muscle cells (6). Neurons have a similar, L type calcium channel. Because $L$ type channels are important in the regulation of intracellular calcium concentration, they may, by inference, be important in various aspects of nerve activity (20). Recent observations by Yoshizawa et al. (21) support the hypothesis that endothelin functions as a neuromodulator through the $L$ type calcium channel. They reported that endothelin is able to induce depolarization of the ventral root in the newborn rat spinal cord. Because both nicardipine and a substance $P$ antagonist inhib- ited the depolarization, the authors postulated that endothelin acted through the dihydropyridine-sensitive calcium channel to stimulate release of the neurotransmitter substance $P$. Thus, it is possible that endothelin may function as a neurotransmitter or neuromodulator by activating the dihydropyridine-sensitive $L$ type channel in neurons of the central nervous system.

\section{Acknowledgments}

The authors thank Tom McVarish for his editorial assistance.

This work was supported by The Bristol-Myers Squibb Pharmaceutical Research Institute and National Institutes of Health grant 5 T32 HL-07208-13 (to M.-E. Lee and K. D. Bloch). M.-E. Lee is a recipient of a Clinician-Scientist Award from the American Heart Association.

Note added in proof. During review and revision of this paper two relevant reports have appeared in the literature. Shinmi et al. (22) have provided biochemical and immunohistochemical evidence for endothelin in porcine spinal cord. Giaid et al. (23) have provided immunocytochemistry and in situ hybridization evidence for the expression of endothelin in neurons of the human spinal cord and dorsal root ganglia.

\section{References}

1. Yanagisawa, M., H. Kurihara, S. Kimura, Y. Tomobe, M. Kobayashi, Y. Mitsui, Y. Yazaki, K. Goto, and T. Masaki. 1988. A novel potent vasoconstrictor peptide produced by vascular endothelial cells. Nature (Lond.). 332:411-415.

2. Komuro, I., H. Kurihara, T. Sugiyama, F. Takaku, and Y. Yazaki. 1988. Endothelin stimulates c-fos and c-myc expression and proliferation of vascular smooth muscle cells. FEBS (Fed. Eur. Biochem. Soc.) Lett. 238:249-252.

3. Badr, K. F., J. J. Murray, M. D. Breyer, K. Takahashi, T. Inagami, and R. C. Harris. 1989. Mesangial cell, glomerular and renal vascular responses to endothelin in the rat kidney. Elucidation of signal transduction pathways. J. Clin. Invest. 83:336-342.

4. Simonson, M. S., S. Wann, P. Mené, G. R. Dubyak, M. Kester, Y. Nakazato, J. R. Sedor, and M. J. Dunn. 1989. Endothelin stimulates phospholipase $\mathrm{C}, \mathrm{Na}^{+} / \mathrm{H}^{+}$exchange, $c$-fos expression, and mitogenesis in rat mesangial cells. J. Clin. Invest. 83:708-712.

5. Takuwa, N., Y. Takuwa, M. Yanagisawa, K. Yamashita, and T. Masaki. 1989. A novel vasoactive peptide endothelin stimulates mitogenesis through inositol lipid turnover in Swiss 3T3 fibroblasts. J. Biol. Chem. 264:7856-7861.

6. Goto, K., Y. Kasuya, N. Matsuki, Y. Takuwa, H. Kurihara, T. Ishikawa, S. Kimura, M. Yanagisawa, and T. Masaki. 1989. Endothelin activates the dihydropyridine-sensitive, voltage-dependent $\mathrm{Ca}^{2+}$ channel in vascular smooth muscle. Proc. Natl. Acad. Sci. USA. 86:3915-3918.

7. Inoue, A., M. Yanagisawa, S. Kimura, Y. Kasuya, T. Miyauchi, K. Goto, and T. Masaki. 1989. The human endothelin family: three structurally and pharmacologically distinct isopeptides predicted by three separate genes. Proc. Natl. Acad. Sci. USA. 86:2863-2867.

8. Bloch, K. D., R. L. Eddy, T. B. Shows, and T. Quertermous. 1989. cDNA cloning and chromosomal assignment of the gene encoding endothelin 3. J. Biol. Chem. 264:18156-18161.

9. Koseki, C., M. Imai, Y. Hirata, M. Yanagisawa, and T. Masaki. 1989. Autoradiographic distribution in rat tissues of binding sites for endothelin: a neuropeptide? Am. J. Physiol. 256:R858-R866.

10. Saper, C. B., D. G. Standaert, M. G. Currie, D. Schwartz, D. M. Geller, and P. Needleman. 1985. Atriopeptin-immunoreactive neurons in the brain: presence in cardiovascular regulatory areas. Science (Wash. DC). 227:1047-1049.

11. Lind, R. W., L. W. Swanson, and D. Ganten. 1984. Angiotensin II immunoreactivity in the neural afferents and efferents of the subfornical organ of the rat. Brain Res. 321:209-215. 
12. Garthwaite, J., S. L. Charles, and R. Chess-Williams. 1988 Endothelium-derived relaxing factor release on activation of NMDA receptors suggests role as intercellular messenger in the brain. Nature (Lond.). 336:385-388.

13. Kingston, R. E. 1987. Guanidinium method for total RNA preparation. In Current Protocols in Molecular Biology. F. M. Ausubel, R. Brent, R. E. Kingston, D. D. Moore, J. G. Seidman, J. A. Smith, and K. Struhl, editors. Greene Publishing Associates and Wiley-Interscience, New York. Unit 4.2, 1-5.

14. Bloch, K. D., S. P. Friedrich, M.-E. Lee, R. L. Eddy, T. B. Shows, and T. Quertermous. 1989. Structural organization and chromosomal assignment of the gene encoding endothelin. J. Biol. Chem. 264:10851-10857

15. Lynch, D. C., T. S. Zimmerman, C. J. Collins, M. Brown, M. J. Morin, E. H. Ling, and D. M. Livingston. 1985. Molecular cloning of cDNA for human von Willebrand factor: authentication by a new method. Cell. 41:49-56.

16. de la Monte, S. M., S. C. Ng, H. Federoff, E. Grabczyk, and M. C. Fishman. 1989. Persistent high-level expression of GAP-43 in a restricted group of neurons in the adult central nervous system. Dev. Brain Res. 46:161-168.

17. Ng, S. C., S. M. de la Monte, G. L. Conboy, L. R. Karns, and
M. C. Fishman. 1988. Cloning of human GAP-43: growth association and ischemic resurgence. Neuron. 1:133-139.

18. Krieger, D. T. 1983. Brain peptides: what, where, and why? Science (Wash. DC). 222:975-985.

19. Yoshida, K., Y. Kawano, M. Kawamura, Y. Hirata, M. Kuramochi, and T. Omae. 1988. Effects of intravenous and intracerebroventricular endothelin on blood pressure in conscious rats. 31st Annu. Meet. Jpn. Soc. Nephrol. Nara, Japan. 263. (Abstr.)

20. Miller, R. J. 1987. Multiple calcium channels and neuronal function. Science (Wash. DC). 235:46-52.

21. Yoshizawa, T., S. Kimura, I. Kanazawa, M. Yanagisawa, and T. Masaki. 1989. Endothelin-1 depolarizes a ventral root potential in the newborn rat spinal cord. J. Card. Pharm. 13(Suppl 5):S216-S217.

22. Shinmi, O., S. Kimura, T. Yoshizawa, T. Sawamura, Y. Uchiyama, Y. Sugita, I. Kanazawa, M. Yanagisawa, K. Goto, and T. Masaki. 1989. Presence of endothelin-1 inporcine spinal cord: isolation and sequence determination. Biochem. Biophys. Res. Commun. 162:340-346.

23. Giaid, A., S. J. Gibson, N. B. N. Ibrahim, S. Legon, S. R. Bloom, M. Yanagisawa, T. Masaki, I. M. Varndell, and J. M. Polak. 1989. Endothelin 1, an endothelium-derived peptide, is expressed in neurons of the human spinal cord and dorsal root ganglia. Proc. Natl. Acad. Sci. USA. 86:7634-7638. 